\title{
Strategic Management of Design as Competitive Differential in Project Management: Scenario and Market Outlook in the Manaus City
}

\author{
Natasha Cristinne Alves Monteiro \\ Universidade Federal do Amazonas, Manaus, Brazil \\ Armando Araújo de Souza Junior, Luis Cláudio de Jesus-Silva, Ana Flávia de Moraes Moraes, \\ Luiz Augusto de Carvalho Francisco Soares, Afrânio de Amorim Francisco Soares Filho \\ Universidade Federal de Minas Gerais, Belo Horizonte, Brazil \\ Sandro Breval Santiago \\ Universidade Federal de Santa Catarina, Santa Catarina, Brazil
}

\begin{abstract}
In recent years, the design has been in evidence and showing the importance in leading companies. Then comes the strategic management of the design, an area of knowledge that aims to add value and competitive advantage to companies through a practical meeting. In this context, this research aims to evaluate the current scenario and projections of this knowledge to the market in the Manaus city, Amazonas, Brazil, and to highlight the importance of it as an important factor in project management. Therefore, we adopted the descriptive and quantitative research carried out data collection through a survey with the purpose of extracting data from key stakeholders: Designers and entrepreneurs. Reputable sources of information reveal that the inclusion of design in business has become a trend with the increasing competitiveness of the global market, in contrast, the results of this research show that the local market is still not a reality, but it is already taking the first steps, which tend in the long-term, increase to an advanced level of management.
\end{abstract}

Keywords: strategic design, project management, Manaus city

\section{Introduction}

This study illustrates the strategic management of design incorporated into the process of project management as a strategic tool of fundamental importance for competitive differentiation in the market, in this

Natasha Cristinne Alves Monteiro, Specialist in Project Management, Universidade Federal do Amazonas.

Armando Araújo de Souza Junior, Doctoral candidate, Administração Department, Universidade Federal de Minas Gerais.

Luis Cláudio de Jesus-Silva, Doctoral candidate, Administração Department, Universidade Federal de Minas Gerais.

Ana Flávia de Moraes Moraes, Doctoral candidate, Administração Department, Universidade Federal de Minas Gerais.

Luiz Augusto de Carvalho Francisco Soares, Doctoral candidate, Administração Department, Universidade Federal de Minas Gerais.

Afrânio de Amorim Francisco Soares Filho, Doctoral candidate, Administração Department, Universidade Federal de Minas Gerais.

Sandro Breval Santiago, Doctoral candidate, Production Engineering, Universidade Federal de Santa Catarina.

Correspondence concerning this article should be addressed to Luis Cláudio de Jesus Silva, Rua Eduardo Ribeiro, 417, São Francisco. CEP: 69.305-140, Boa Vista, Roraima, Brazil. E-mail: luisclaudiojs@gmail.com. 
case the city of Manaus, where it is checked initially, based on unsubstantiated assumptions, the lack of this activity in the current models of project management.

According to Minuzzi, Pereira, and Merino (2003), the subject of strategic management design is a recent subject in Brazil and still very little spread in the organizational culture of large national companies, either in the northern region. A reality that arises, among other factors, the high resistance of managers to believe and invest in innovation and creativity in the growth of the competitive capacity of their own projects and the company that he/she manages. This view, however, comes in disagreement with the current market trends, which due to the fierce competitiveness that progressively reaches higher and higher levels, requires companies and their products and/or services assume a different position to ensure their own survival in the market, since the use of traditional tools and factors such as price and quality, let alone be decisive for the guarantee of success.

Câmara, Monteiro, Oliveira, Mendonça, and Botelho (2006) nodded to the innovation process as a factor which depends increasingly on the ability of a company to compete in the medium and long term, which means that innovation is intrinsically related to the management itself. The author further states that the coverage of the design exceeds the limits and functions merely aesthetic, and should be seen more than that, but as a tool for innovation for the competitiveness of companies.

Based on this speech, such work is to develop a study aimed at understanding the concept and use of strategic management of design projects, with an emphasis on benefits and contributions that this tool can offer to companies as an active differentiator in business competition, justifying an investigation of the current scenario and market prospects (industry, trade, and service goods) that the present context of the city of Manaus prospects for the future with regard to the strategic management of the design.

According to Zurlo (2010), as the design process provides a movement of transformation, it is an open system that allows and offer different points of view, and interpretive models articulated and several prospective disciplinary. Through the collective thinking of the typical design, which in turn will be reflected in production value for customers, partners, employees and other stakeholders, the strategic design has an inherent capacity to enable a process of dialogue between various actors and brings a characteristically strategic action as cause and effect of a collective and iterative process that can change reality (Zurlo, 2010).

To corroborate this statement, was first drafted a survey data collection, which results indicated the level of information of businesses in the city about it and use made of this tool in their day to day management activities.

The evaluation was based on quantitative sampling gathered, which in turn helped in obtaining a science of the real situation of the problem in question, and strengthened the hypothesis that the lack of knowledge about design management within the market, as attests Fascioni (2008), which also warns of education institutions, restringeem very competitiveness of domestic firms.

\section{Theoretical Foundations}

\section{Understandings of Design}

In times where information is increasingly more dynamic and integrated to a greater number of communication channels, the word design has been gradually introduced to the everyday and popular vocabulary, however, their understanding is often missing or erroneous, distorting the concept of design assignments practices that do not compete with its main feature: the projecting. But conceptualize and define their practices, it is one of the easiest tasks, considering that there are discussions and differences of concepts within the academic and professional community in the area that do not come to a common denominator 
bounded, considering that it is a profession that goes through constant change influenced by different historical moments, as well as having affinities with art, since both are characterized as creative activities, as commented by Costa Jr. (2009).

For Best (2006, p. 112), “design is strictly a cyclical process of inquiry and creativity”. The design process consists of a series of methods and together with the nature of each project or design issues, and is not linear because it has many cycles defined to allow the interactive nature of the design and accommodate insights at each stage of the process.

Starting from the etymological principle of the word, we see in Cardoso (2004) that the earliest origin comes from Latin designare, meaning design and drawing at the same time. While the English language refers to both the plan view, intention, purpose, as the arrangement and structure.

The author explains the origin and meaning of the word itself, it has cause an ambiguity between the abstract (subjective, conceptual) and concrete (objective, practical) to shape things, however, is knowledge and acceptance general the design works on these two levels, so characterized, and becomes an essentially projective activity.

Brown (2009) proposed that design thinking is an approach that uses the designer's sensibility and methods to solve problems and meet the needs of people with a viable technology and commercially practicable. Hence, design thinking is the user-centric innovation, which demands collaboration, interaction, and practical approaches to find the best ideas and ultimate solutions. And yet, the design before interpreted as a task in the development of new products, may spread their "projective thinking” (design thinking), capillary organization and, especially, its administration, proposing the project as a new paradigm innovation.

Conceptualizations aside, Sperb (2009) showed that the Random House Unabridge Dictionary situates the origin of the word in the period of 1350-1400, when the design was combined with other fields of knowledge (mathematics, physics, engineering, and poetry) to creating mechanical watches. But it was only during the European Renaissance, the expression obtained a clearer sense primarily for traders, who realized that using the return could bring design to business to differentiate their products through the competition of European trade.

It is seen in the literature almost entirely, that the industrial revolution in the 21st century was the framework for the emergence of the professional practice of design, considering its formation that period as project activity can define the formal properties of the product "creating an interface relationship with the consumer and their needs, contributing to the creation of trends and generating market demands” (Lemos, 2009).

The historical process started from then transformed and expanded the powers of design, overstepped the boundaries of the industry and also migrated to the service economy, expanding its multidisciplinary and acquiring greater creative freedom to wander through the various fields of knowledge, besides taking its functions initially dedicated to industrial purposes, other new responsibilities (Franzato, 2010).

\section{Design Management and the New Economy}

One of the biggest challenges faced by organizations in recent years, according to Miolo (2006), has been keeping up on the competitiveness of the market in the face of constant changes resulting from globalization, which therefore requires multinationals to compete with small businesses, which are broaden the choices of products and services offered to consumers. These, in turn, become more demanding compared to the increase of this offering, raising the companies' greater concern to meet the expectations of these customers through differentiation and innovation, which are nothing more than design essentials. 
Regarding these changes, Duisemberg (2008) spoke of the emergence of a creative economy that replacing the traditional models of production, focuses on human talent and innovation as tools for the promotion of development compared to a constantly changing scenario, where parameters, models, and trends are quickly replaced by others in a dynamic ever-accelerating events. Moreover, the approach of the creative economy permeates the concept of innovation, like Sawhney, Wolcott, and Arroniz (2006) that defined as creating substantial value for customers and companies and emerges from a combination of factors, with the knowledge of its key inputs.

Given the scenario presented, the design approach within companies figure changed, becoming seen as a powerful competitive advantage. Found in the brief narrative of Crumb (2006) as an understanding of this transition:

The awareness of the importance of managing this process for entrepreneurs, industrialists, researchers, and designers themselves, led to the development of ways to manage the design, seeking its systematization and control, as well as their consistent application. Thus, the design management is now consolidated as the study area and various business initiatives, government, and consulting institutions (Miolo, 2006).

The management of the design has been widespread within organizations, especially in the economic advanced countries such as the United States and European countries, where the relationship between these two fields of knowledge are already understood and valued in the face of a culture of design more mature compared the Latin American countries (Campos, Andrade neto, Silva, Paschoarelli, \& Landim, 2010). This detachment is clear considering the historical factor, as the example of Europe, the management of the design came from the 1960s, with the award initiatives and scientific publications on design management approaching and discussing about the role of design in the economy and in business, apart from order to recognize the value and contributions that this knowledge could lead to managerial environment (Minuzzi, Pereira, \& Merino, 2003). Brazil, by contrast, still has a few companies investing effectively in design, especially considering the history of the Brazilian market, which until a few decades ago, suffered late in relation to the outside regarding the modernization of the industry (Santos, Silva, \& Telles, 2008).

Possibly, the combination of these two areas could be due to the affinity they have in common, if we ponder what is glimpsed in Mozota (2002), that the design is not only in close up around a creation activity, coordinator, and systemic, but especially focuses on solving problems just like project management, thus manifesting a proximity between areas seemingly unnoticed.

In a comparison between schematic design and management presented by the author, visualize the similarities that can be found (see Table 1).

Table 1

Relations of Convergence Between Design and Management

\begin{tabular}{|l|l|}
\hline Management & Design \\
\hline Process, troubleshooting & Problem solving activity \\
\hline Management ideas, innovation & Creative activity \\
\hline Enterprise systems, information & Systemic activity \\
\hline Communication, structure & Activity coodination \\
\hline Culture of the organization & Cultural activity and artistic \\
\hline
\end{tabular}

Note. Source: Mozota, 2002.

Many points in common can be understood based on the assertion of Fascioni (2008), "design is the 
embodiment of the brand's personality, values, and goals of the company, existing independently of the will or consciousness of its managers". If the design is inherent in a company since its inception and common to all others, the same differentiation from the competition will be in the way, the "how" design management will be made so that their strategies are planned and executed in alignment with your goals.

Wolf (1998) defined the role of design management as just a plan and manages the strategies corresponding to the goals and values of the company, through proposals to ensure compliance with the objectives, respecting deadlines and estimated costs.

In the midst of this process, the author argues that design management can be conducted in parallel with the strategic and operational levels, known respectively as the strategic management of design and operational management of design.

\section{Strategic Relations of the Design and Design-Thinking}

From the perspective of Magalhães (1997), the strategic design is defined as a form of action directed toward the management of design in business, where corporate image and products are integrated into the organization's strategies using the process as a catalyst and synthesizer materializing knowledge and information on products and services.

The design concept related to strategy and innovation began to be formalized as a discipline since 1975, in Boston, with the emergence of the Design Management Institute (DMI).

In this sense, the designer is noted as an agent of the process more strategic and not exclusively operating a preset profession commonly absorbed by managers and by society in general. In this sphere, it is understood that the professional has knowledge that allow you to not only troubleshoot aesthetic and functional nature of products and services, as well as participate in the planning stages, production, management, and marketing (Balem, Fialho, Cardoso, \& Souza, 2009).

This assertion is understandable if we consider that the multidisciplinary areas in which the design focuses (see Figure 1), provides grants to professional to interact with human cognition and manage visual information and theoretical knowledge to properly assume the role of the creative driver development projects.

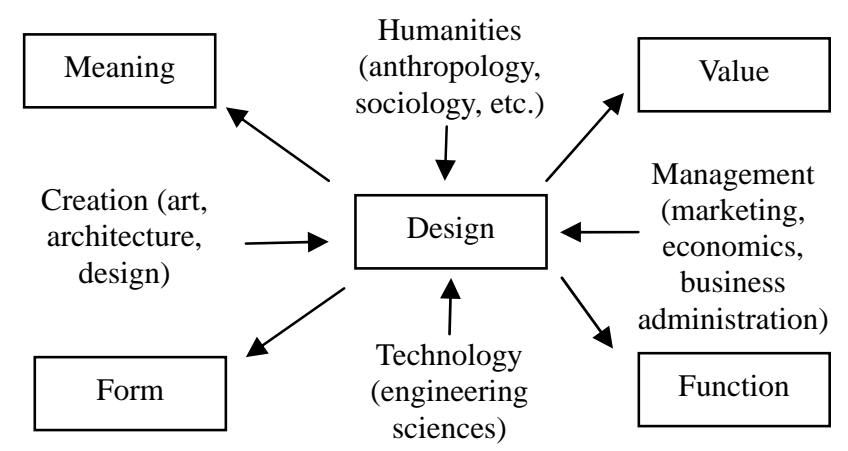

Figure 1. Design skills and related areas. Retrieved from http://www.simbiozi.com.br.

Design is a value added, is to deal with emotions, human desires, experiences, is to create value and materialize it into products and services, generating solutions actually relevant and effective to allow the company to recognize and rethink their position before positive the consumer.

Organizations worldwide relevance as Apple, Kia, Nike, Sony, among many others, have already paid attention to the design and incorporated as an essential part of their business, after all, design helps sell, and 
very (Hanson \& Nitzsche, 2010). Undoubtedly, each of them at one time felt the need to focus on innovation as a way to ensure your stay in the market and decided to invest in the intangible value of their corporations, to quote the corporate image, the relationship of consumers with the brand and experiences of use, among others, are some of the many attributes that currently respond better corporate performance of firms in the market.

For Martin (2009), design thinking is to form a context instead of taking it as it is, i.e., the concept deals primarily with what does not yet exist, deepening the analysis.

With bases embedded in the work and development of these values (intangible), then rises to just over 10 years the concept of design thinking. Its definition varies from author to author, some call mental model, other methodology or concept, but among the numerous variations, is given in Kiss (2010), that the expression is actually a recent term to describe the concept does not as recent as well. Demarchi, Fornasier, and Martins (2010) added "Design thinking is not a new concept or a new practice, as long as there is no design".

Also in this line, Cardon (2010) described the design thinking as "a useful tool that applies the creative and critical thinking to understand, visualize, and describe complex or ill-structured problems and then develop practical approaches to solve them".

To Viana, Vianna, Adler, Lucena, and Russo (2012) is design thinking an "approach focused on the human being, who sees in multidisciplinary, collaborative and tangibilization thoughts and processes, pathways that lead to innovative solutions to business”, Martin (2010) stands in the same conceptual treadmill.

For Lockwood (2009) its definition is nebulous. The English dictionaries distinguish thinking of (thinking of), thinking about (thinking about), and thinking through (think through), concluding that design thinking meets the three.

Design thinking is essentially "a process of human-centered innovation that emphasizes observation, collaboration, fast learning, visualization of ideas, rapid prototyping concepts and business analysis of competitors, to influence innovation and business strategy” (Lockwood, 2009, p. 11).

Based on this speech, like many others, means that the definition is the same design strategy, however, as the term itself already expressed, design thinking refers to the designer called way of thinking, to seek solutions in different ways and unconventional in the business, the famous "think outside the box". And think like a designer means to systematize the process in stages and be guided by a method (see Figure 2) that leads to the solution of the problem.

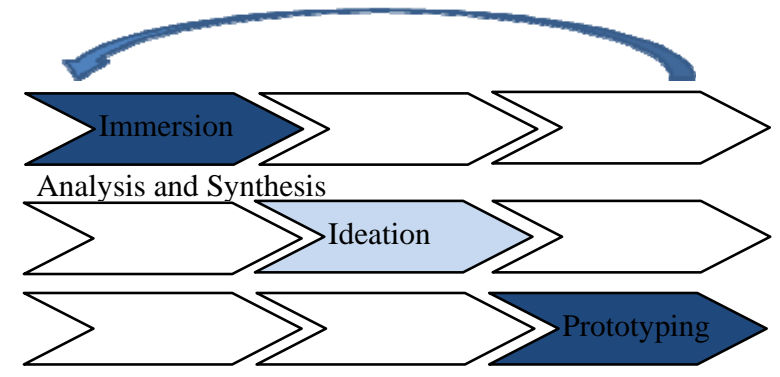

Figure 2. Schematic representation of the stages of design thinking. Source: Viana et al., 2012.

In Brown (2009), ideation is the process in which ideas and concepts are generated and prototyped in order to generate innovations on the problems identified in step immersion.

The apparent linearity of the process is not exactly in practice, since the model is flexible in every problem situation, allowing steps are conducted independently of sequence, with freedom to combine the three steps 
immersion self-explanatory, suicidal ideation, and prototyping as the need for the project.

\section{Manaus From the Perspective of Economic Development}

Located in the center of the largest preserved green area in the world, Manaus concentrates most of the total population of the state of Amazonas, which is nothing less than the equivalent of 1,882,423 million inhabitants living only in the capital, according to the 2010 Census, the Brazilian Institute of Geography and Statistics (IBGE), occupying seventh place in the ranking of the most populous cities of Brazil, behind the cities of São Paulo, Rio de Janeiro, Salvador, Brasilia, Fortaleza, and Belo Horizonte.

The city has its economic base signed the Industrial Pole of Manaus Free Zone, created as a project proposal initially geopolitical nature of the end of the 1960s, after the long period of economic stagnation that followed the decline of the so-called golden age of the rubber (Loureiro, 2003).

According to the author, Free Trade Zone is the result of an agreement between the federal, state, and municipal government of the time who contributed to the creation of incentives under the capable to attract industries to settle in the region to compete equally with other markets even before the barrier of location factors and logistics.

The Free Trade Zone model is today considered the most successful project of Brazil in relation to regional development, bringing together large companies nationally and internationally renowned under an industrial base tends to be expanded, opening doors to other segments, such as production of from regional raw materials, as exemplified by Loureiro (2003).

It is under this pillar that Manaus has developed, generating and accumulating capital, developing other markets, such as goods service, for example, and forming own human resources. These in turn are not limited to the vicinity of the industrial complex, quite the contrary, spread out into other areas, especially regarding the tertiary sector (trade), creating a demand for professionals and local businesses of a non-existent until recently time ago.

Concerning this sector, Pimentel (2008) nodded to place a trade representative and relevant participation in the revenue generation of the state. The 2010 report of the Department of Planning and Economic Development (SEPLAN) shows that just over 10 years there has been an expansion of this sector with the growth of the city, thus characterizing a decentralization of local trade, given that mobility was the center to the outlying areas over the last few years.

Although the Industrial Pole of Manaus is the largest shareholder of the economic growth of trade consequently drives the maturation of other areas related to it, such as communication (advertising, design, marketing) that realizes the growing number of advertising agencies that have expanded its portfolio of clients with the emergence of new business in the tertiary sector.

Manaus development prospects and the economy was a factor that increased the capital to the category of best city in the region to invest in business and make a career, according to sources Exame Magazine and FGV (2008), but the fact of the matter is that this growth does not restricted only to the field of industry, but also to other areas whose activities have competitive potential that goes against an expansion of possibilities of action market.

\section{Methodology Course}

The methodological procedures intended to gather information that addresses the results to draw a scenario corresponding to the actual state of the environment investigated: The market manauara (industry and services). 
Thus, it was considered the relevance of performing quantitative survey to obtain information of the subjects: Designers and entrepreneurs (companies/clients).

In quantitative terms, the results obtained by collecting data are measured by numbers, helping to draw the scene to be identified. In this regard, Barbosa (1998) explained that the quantitative tools used to obtain numerical indices corresponding to specific characteristics of people or objects measuring, presenting quantitative indicators and providing accurate results (Oliveira, 2006).

Therefore, the study is conducted by the method of field research, defined by Rodrigues (2007) as the method to observe the facts as they occur, without isolating and controlling variables for the established relationships are perceived and studied. It is a descriptive-quantitative, since it is based on quantitative data collection techniques and uses data from questionnaires, forms, interviews and other (Carnevalli \& Miguel, 2004).

Under this line of research, the objective is to use a questionnaire to inquire and extract information from subjects in order to identify which variables and influence the construction of the existing scenario for performance of strategic design in the market of Manaus. Based on these characteristics, the technical procedures adopted are defined as survey, because as elucidated by Coelho and Turrione (2009), this is an instrument that "involves the direct interrogation of individuals whose behavior you want to know". Freitas, Oliveira, Sacoll, and Moscarola (2000) described the use of survey convenience when:

- Aims to answer questions like "what?", "Why”, "how", and "how much?”, i.e., the focus of concern about "what is happening" or "how and why this is happening";

- Not if you are interested or cannot control the independent and dependent variables;

- The natural environment is the best situation for studying the phenomenon of interest;

- The object of interest occurs in the present or in the recent past.

Data collection is made from two types of questionnaire with multiple choice questions aimed at designers and representatives of local businesses that were part of the sample voluntarily, characterized as non-probabilistic by convenience, in order that is a "selection of sample units more easily accessible" (Dias, 2009). The calculation of data is guided by the tools of descriptive statistics, defined by Vieira Neto (2004) as an area of statistics that uses the exploratory analysis to describe and summarize conclusive data about the population of interest.

The basic goal of descriptive statistics is to summarize a range of values of the same nature, which in turn allow the researcher to obtain an overview of the variation of these values, describing and organizing the data in three ways: tables, graphics, and descriptive measures (Guedes, Martins, Acorsi, \& Janeiro, 2012).

\section{Search Results}

The study was targeted at design professionals and representatives/local business owners from various segments which have created two types of questionnaires: The first, aimed at designers, consists of 11 multiple choice questions and one open, which is optional to the respondent, totaling 12 questions. For businessmen, were targeted seven multiple choice questions and one of type box, where the respondent could choose up to three options to structure your answer.

In total, 65 responses were gathered from 53 designers and entrepreneurs, whose application was made for forms online via Google Docs directed to the target audience via email and social networks during the month of August 2012. 
At first, we analyzed the results of the data collection done with design professionals living and working in Manaus. Sampling evaluated, $52 \%$ of respondents are female and $48 \%$ are men, composing a group of individuals in which $61 \%$ received training in public education institution and $49 \%$ in private. The sample also reveals that most participants completed the course in the period 2007-2011, with some exceptions for the earliest period, 1996 and newer, 2014.

Among the main areas, $61 \%$ of professionals are skilled in the two main areas of design: visual programming and product. Another $16 \%$ are formed only in the area of visual programming, $11 \%$ digital interface, $9 \%$ in product design, and 3\% in other areas (see Figure 3).

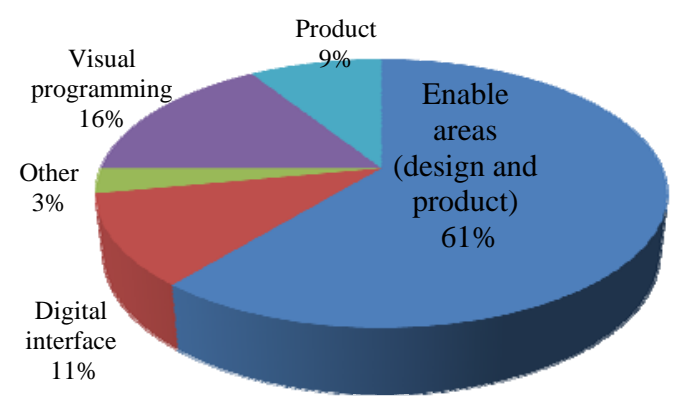

Figure 3. Key qualifications design sample. Source: Research data, 2012.

The evaluated group, 52\% work in graphic design, representing a large portion of respondents with a significant difference compared to other areas: web (9\%), product (5\%), interior design (3\%), and others (30\%).

Information that proved different from what was expected by the research was the fact that there is a higher concentration of respondents working in private companies, about $28 \%$. This represents the occurrence of a decentralization of these professionals who migrated communication agencies (which according to the sample, holds $15 \%$ of designers) for businesses. And these in turn have absorbed considerably this demand, which was not a reality until a few years ago. For other responses, we have the following result: $18 \%$ working from home/freelance, $12 \%$ in educational institutions, which represents the same percentage for those who are employed in research institutes (the same 12\%), while only 6\% work in design offices and $5 \%$ in other places (not specified) (see Figure 4).

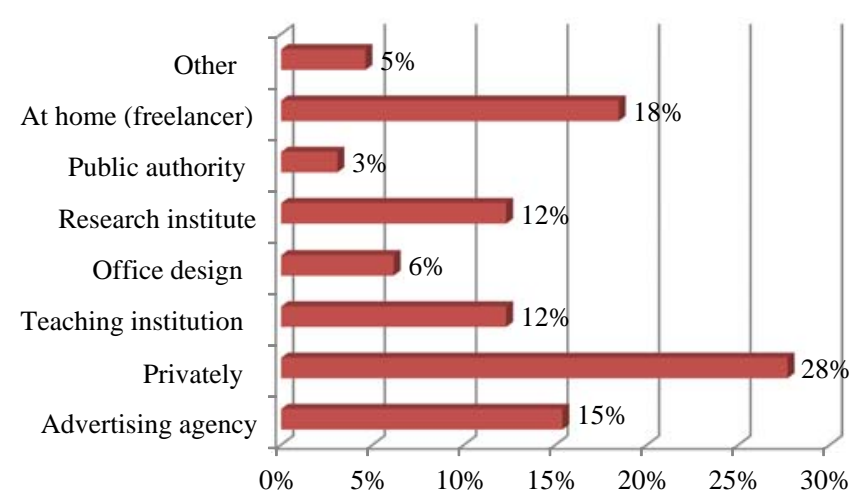

Figure 4. Workplaces of designers. Source: Research data, 2012.

When asked about the knowledge about the strategic management of the design, the majority, $92 \%$ of respondents proved knowledgeable, against $8 \%$ who have never heard about it. In contrast, 55\% have 
reasonable knowledge in terms of depth of content. Parallel to this, those who master the subject follow the same proportion of those who know little, representing a percentage of $19 \%$ each.

The previous results also reflect on work practices, where the frequency of application of knowledge is converted into $47 \%$ for applying strategic management in their projects infrequently, 22\% never used it, $18 \%$ rarely do and $13 \%$ for those who frequently implement (see Figure 5).

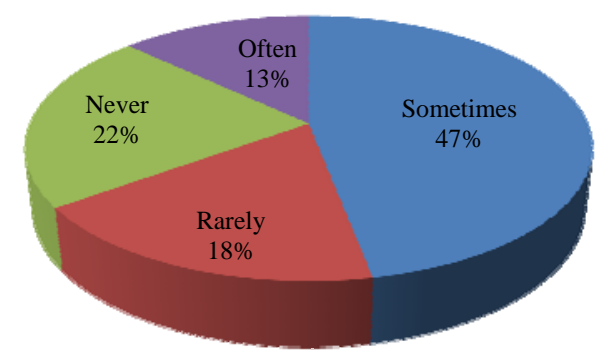

Figure 5. Application of strategic management of design work. Source: Research data, 2012.

Regarding the companies that participated in the survey, $60 \%$ corresponds to the category of trade goods and services, and most of average (23\%) to large (30\%), with a participation of $5 \%$ of small businesses. The remaining $40 \%$ equivalent to industry category, representing the involvement of companies large-, medium-, small- and micro-sized at 23\%, $8 \%, 11 \%$, and $2 \%$ respectively (see Figure 6 ).

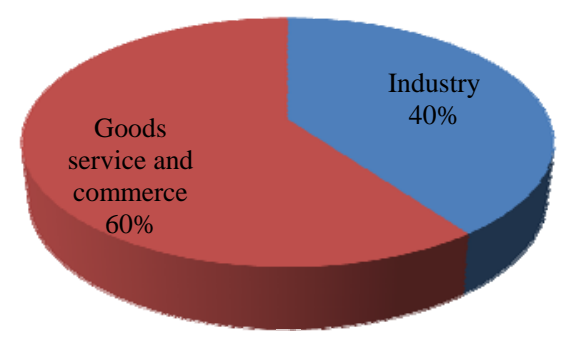

Figure 6. Category of the sample companies. Source: Research data, 2012.

When asked about the three main attributes of the company, products and services they deemed as priorities in their organizations, the quality factor topped $79 \%$ in the options of choice, followed by credibility (51\%) and other (36\%), which included mainly the tradition as one of the most frequent responses (see Figure 7).

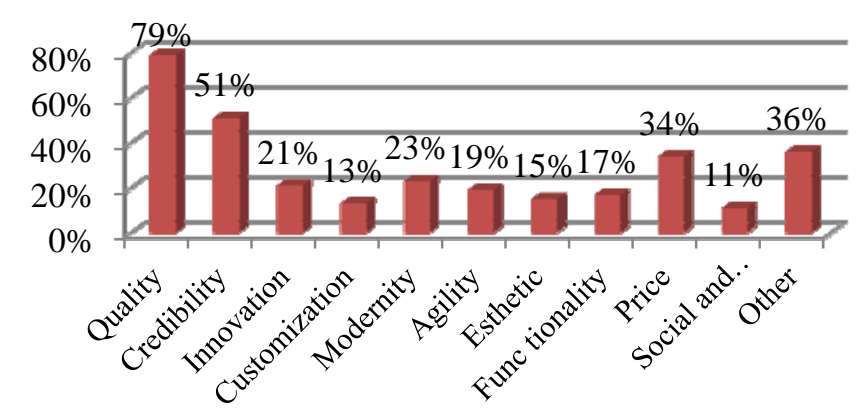

Figure 7. Key attributes of the companies. Source: Research data, 2012. 
The results revealed that slightly more than half of all companies surveyed (51\%) have their goals set by the owner or president, sequentially the marketing department (22\%) and management/administrative direction (21\%) were the second and third most voted option respectively (see Figure 8).

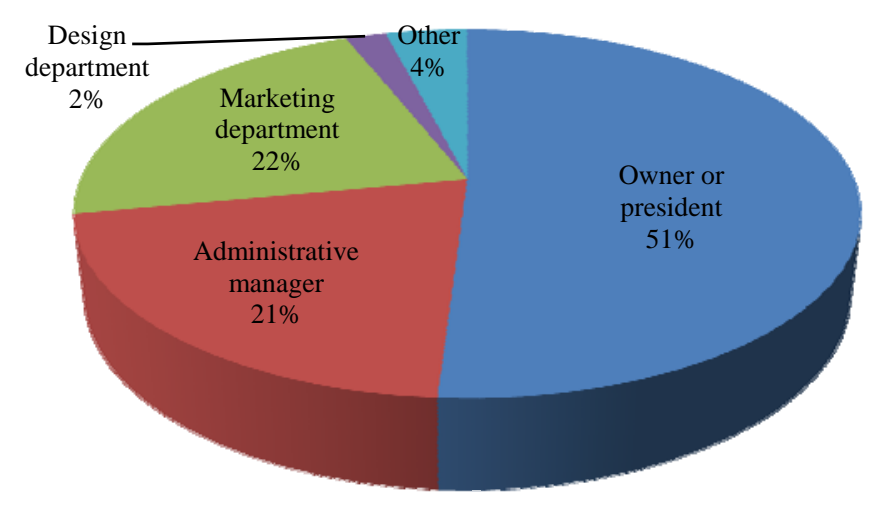

Figure 8. Key managers of corporate goals. Source: Research data, 2012.

It was also found that about $50 \%$ of local businesses have no designers involved in the strategies of the business and $47 \%$ yes. A small difference to what was expected compared with the survey results of the other group investigated.

When asked about their knowledge on the subject of strategic design management, there is a balanced distribution of responses, 30\% said that they had heard about it and have dominion what it is, others also know $35 \%$ of existence of such knowledge, but do not understand what it is and 35\% attests not yet know anything about the subject (see Figure 9).

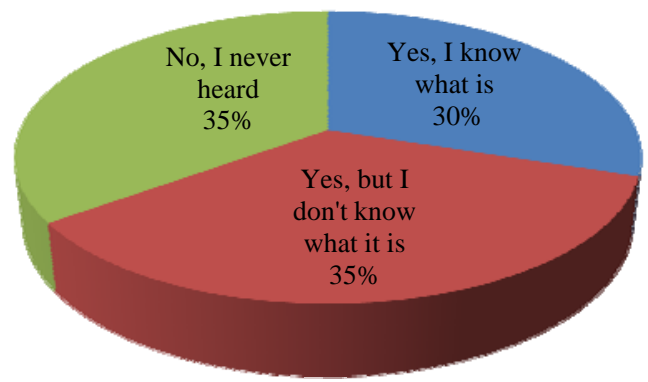

Figure 9. Assessment of knowledge about strategic management of design. Source: Research data, 2012.

The most comprehensive reveals that a significant $87 \%$ of local businesses do not adopt the management of design in their business, compared to $13 \%$ who say use knowledge, confirming the initial hypothesis that the practices of design management in the city of Manaus are in the early stage and their representation is still very low.

\section{Final Thoughts}

The management of the design has been enhanced over the past years as a differentiating agent organization in the market competition. Its importance within large companies is large, making their inclusion in the process of project management is more necessary. A reality opposite to what happens in Brazil, even 
more so in the regions outside the south-southeast axis.

The past is still very new design in the country, mainly and specifically in the city of Manaus, is the initial assumption that leads to the current scenario evaluated. Considering that the creation of the first university degree from the Federal University of Amazonas, for example, when a little over 20 years only.

The introduction of the profession in the northern region has shown gradual, like other technologies, whose disparity relative to other urban centers, especially the cities of the southeast, is still high. Similarly occurs with the design.

Based on the results obtained, the evaluation lead to a local market still maturing stage and already shows positive changes, but still are significantly distant from developed markets and the strategic aspect of innovation.

This study was the confirmation of what is already felt by designers who develop their activities in Manaus: ignorance. On the one hand, entrepreneurs who know little value, differentiation, and innovation that strategic design can add to their businesses, and secondly, the health professionals who are not encouraged to be strategic and entrepreneurial in college and entering the labor market in large with the operational profile. In this sense, lacking professional trained to work at a strategic level in a place where the vast majority have reasonable knowledge of the subject, pointed as the study itself.

The manauara market still has much to be explored, including this, is the reason commonly hear that this is a "land of opportunity", because it is a relatively young, still being completed, already visible in some aspects, e.g., the numbers reporting agencies which have grown significantly in recent years, the quality of actions, campaigns, advertising, and promotional material that has been showing frequent, representing a direct reflection of a change in attitude and positioning of companies. Otherwise, there would be no customers demand to absorb these agencies that come every year.

The relationship of strategic management of the design and the local market (industry, trade, and service goods) can be understood as a process that goes gradually to development, natural consequences, such as increasing competitiveness in all aspects, for example, lead the current scenario to another level, where innovation strategies will take priority as a matter of survival for the market.

\section{References}

Balem, F., Fialho, F., Cardoso, H., \& Souza, R. (2009). Design thinking: Conceitos e competências de um processo de estratégias direcionado a inovação. Disponível em. Retrieved May 20, 2012, from http://www.desenhandoofuturo.com.br/anexos/anais/designe_inovacao/design_thinking_implementacao_de_um_processo_d e_estrategias_direcionado_a_resultados_inovadores.pdf

Barbosa, E. (1998). Instrumentos de coleta de dados em projetos educacionais. Retrieved April 24, 2012, from http://www.tecnologiadeprojetos.com.br/banco_objetos/\%7B363E5BFD-17F5-433A-91A0-2F91727168E3\%7D_instrument os\%20de\%20coleta.pdf

Best, K. (2006). Design management: Managing design strategy, process and implementation. Switzerland: AVA Publishing SA.

Brown, T. (2009). Change by design: How design thinking transforms organizations and inspires innovation. New York: Harper Collins.

Câmara, J., Monteiro, R., Oliveira, W., Mendonça, L., \& Botelho, R. (2006). A gestão do design na concepção de novos produtos e a diferenciação mercadológica. Retrieved May 22, 2012, from http://fido.palermo.edu/servicios_dyc/encuentro 2007/02_auspicios_publicaciones/actas_diseno/articulos_pdf/A3115.pdf

Campos, L., Andrade neto, M., Silva, J. C., Paschoarelli, L. C., \& Landim, P. (2010). Industrialização brasileira: Implicações no design hoje. Retrieved June 1, 2012, from http://blogs.anhembi.br/congressodesign/anais/artigos/69842.pdf

Cardon, E. C. (2010). Unleashing design: Planning and the art of battle command. Military Review, 90(2), 2-12. 
Cardoso, R. (2004). Uma introdução à história do design. São Paulo: Edgard Blücher.

Carnevalli, J. A., \& Miguel, P. A. (2004). Desenvolvimento da pesquisa de campo, amostra e questionário para realização de um estudo tipo Survey sobre a aplicação do QFD no Brasil. São Paulo: Revista Gestão e Produção.

CENSO. (2010). Retrieved July 22, 2012, from http://www.censo2010.ibge.gov.br/

Coelho, A. F., \& Turrione, J. (2009). Validação de instrumento para medição de práticas de gestão de qualidade em empresas certificadas ISO 9001 e sua aplicação emItajubá. Revista P\&D em Engenharia de Produção, 8, 86.

Costa Jr., H. (2009). Entre arte e design: Sobre afectos e afecções na obra de Guto Lacaz. Retrieved May 20, 2012, from http://www.gutolacaz.com.br/artes/textos/ArteDesign.pdf

Demarchi, A. P., Fornasier, C., \& Martins, R. (2012). Design Thinking no Processo de Gestão de Design: um estudo de caso na agricultura familiar. Retrieved June 8, 2012, from http://blogs.anhembi.br/congressodesign/anais/artigos/69404.pdf

Dias, R. (2009). Métodos de Amostragem Cálculo do tamanho de amostras. Retrieved June 8, 2012, from http://www.leb.fmvz.usp.br/ensino/pos-graduacao/vps5702/exercicios/amostragem-2009

Duisemberg, E. (2008). A Economia Criativa: Uma Opção de Desenvolvimento Viável?. In A. Reis (Ed.), Economia Criativa Como Estratégia de Desenvolvimento: uma visão dos países em desenvolvimento. São Paulo: Itaú Cultural.

Fascioni, L. (2008). Considerações sobre a formação dos gestores de design no Brasil. Retrieved June 22, 2012, from http://www.ligiafascioni.com.br/wpontent/uploads/2010/08/GestoresDesign.pdf

Franzato, C. (2010). O Design Estratégico no Diálogo entre Cultura de Projeto e Cultura de Empresa. Retrieved May 5, 2012, from http://www.unisinos.br/sdrj/pdf/89.pdf

Freitas, H., Oliveira, M., Sacoll, A., \& Moscarola, J. (2000). Método de Pesquisa Survey. Retrieved July 22, 2012, from http://www.praticadapesquisa.com.br/2010/09/pesquisa-survey.html

Guedes, T., Martins, A. B., Acorsi, C., \& Janeiro, V. (2012). Estatística Descritiva. Retrieved July 22, 2012, from http://www.ebah.com.br/content/ABAAAATxYAI/estatistica-descritiva\#

Hanson, D., \& Nitzsche, R. (2010). Designing, a Transformação do design estratégico. Retrieved May 15, 2012, from http://www.aedb.br/seget/artigos07/11_Hanson\%20e\%20Nitzsche\%20Designing.pdf

Kiss, E. (2010). A evolução do design estratégico: Entrevista concedida à HSM. Retrieved June 17, 2012, from http://wn.com/hsm_entrevista_ellen_kiss

Lawson, B. R. (1990). How designers think. London: Butterworth Architecture.

Leavy, B. (2010). Design thinking: A new mental model of value innovation. Strategy and Leadership, 38, 5-14.

Lemos, R. F. (2009). Soluções de Inovação em Design. Retrieved July 15, 2012, from http://www.go-to-idee.com.br/public/uploads/artigos/RFLemos4PeD.pdf

Lockwood, T. (2009). Design thinking: Integrating innovation, customer experience, and brand value. New York: Allworth Press. Loureiro, M. (2003). O Papel Estratégico da Zona Franca de Manaus no desenvolvimento da Amazônia. Revista T\&C Amazônia.

Magalhães, C. (1997). Design estratégico: Integração e ação do design industrial. Estudos em Design, III(1), 15-27.

Martin, R. (2010). Design thinking: Achieving insights via the knowledge funnel. Strategy and Leadership, 38, 37-41.

Martin, R. L. (2009). The design of business: Why design thinking is the next competitive advantage. Boston, M.A.: Harvard Business Press.

Minuzzi, R., Pereira, A., \& Merino, E. (2003). Teoria e Prática na Gestão do Design. Retrieved May 8, 2012, from http://200.145.152.5/ paula/Paula/teoria.pdf

Miolo, R. (2006). Gestão do Design e Design Estratégico: aplicação ao modelo atual da Esmaltec s/a. Retrieved July 12, 2012, from http://www.artigos.com/artigos/sociais/administracao/gestao-do-design-e-design-estrategico-5181/artigo/

Mozota, B. (2002). Design management. Paris: Éditions d'Organisation.

Oliveira, T. (2006). Amostragem não probabilística: adequação de situações para uso e limitações de amostras por conveniência, julgamento e quotas. Retrieved June 22, 2012, from http://www.fecap.br/adm_online/art23/tania2.htm

Pimentel, N. (2008). Desenvolvimento Econômico Regional-O Comércio de Manaus I. Retrieved June 22, 2012, from http://www.seplan.am.gov.br/arquivos/download/arqeditor/publicacoes/artigos/Nilson_Pimentel/24Desenvolvimento-Econo mico-Regional-O-Comercio-de-Manaus-I.pdf

Rodrigues, W. (2007). Metodologia científica. Retrieved June 22, 2012, from http://professor.ucg.br/Site Docente/admin/arquivosUpload/3922/material/Willian\%20Costa\%20Rodrigues_metodologia_cientifica.pdf

Santos, C., Silva, V., \& Telles, M. (2008). Concurso: Design brasileiro ganha novo prêmio. São Paulo: Revista Inovação em Pauta.

Sawhney, M., Wolcott, R. C., \& Arroniz, I. (2006). The 12 different ways for companies to innovate. MIT Sloan Management 
Review, 47(3), 75-81.

Secretaria de Estado de Planejamento e Desenvolvimento Econômico (SEPLAN). (2012). Retrieved June 29, 2012, from http://www.seplan.am.gov.br

Sperb, D. (2009). Não existe, mudança, inovação ou desenvolvimento sustentável sem design. Retrieved May 20, 2012, from http://dqsperb.files.wordpress.com/2009/05/design-estrategico1.pdf

Sundström, P., \& Zika-Viktorsson, A. (2009). Organizing for innovation in a product development project combining innovative and result oriented ways of working: a case study. International Journal of Project Management, 27(8), 745-753.

Viana, M., Vianna, Y., Adler, I. K., Lucena, B., \& Russo, B. (2012). Design thinking: Inovação em negócios. Rio de Janeiro: MJV Press.

Vieira Neto, P. (2004). Estatística descritiva: Conceitos básicos. Retrieved May 20, 2012, from http://uni.educacional.com.br/up/59960001/3103751/Apos_Est_I_Fev04_C1.pdf

Wolf, B. (1998). O Design Management como fator de sucesso. Florianópolis: IEL.

Zurlo, F. (2010). Design strategico. Roma: Editore Enciclopedia Treccani. 